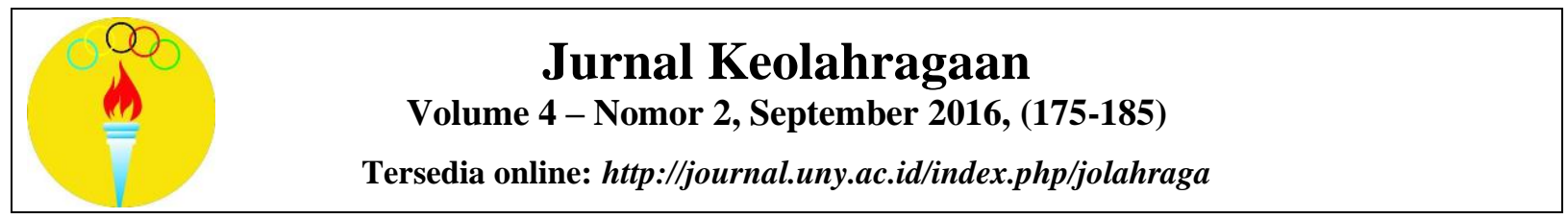

\title{
PENGEMBANGAN PEMBELAJARAN TEKNIK DASAR BULU TANGKIS BERBASIS MULTIMEDIA PADA ATLET USIA 11 DAN 12 TAHUN
}

\author{
Ghazali Indra Putra ${ }^{1} *$, FX. Sugiyanto ${ }^{2}$ \\ ${ }^{12}$ Program Studi Ilmu Keolahragaan, Program Pascasarjana, Universitas Negeri Yogyakarta. Jalan \\ Colombo No 1, Karangmalang, Yogyakarta 55281, Indonesia \\ * Korespondensi Penulis. Email: indrapazky@ yahoo.com,Telp: +62274-586168
}

Received: 16 September 2016; Revised: 3 October 2016; Accepted: 31 October 2016

\begin{abstract}
Abstrak
Penelitian ini bertujuan untuk menghasilkan media pembelajaran teknik dasar bulu tangkis berbasis multimedia. Penelitian pengembangan ini dilakukan dengan langkah-langkah sebagai berikut: (1) tahap studi pendahuluan, (2) validasi ahli, (3) uji coba lapangan, dan (4) pembuatan produk akhir. Data dikumpulkan menggunakan instrumen: (1) validasi produk awal, (2) angket observasi untuk pelatih dan ahli materi, dan (3) lembar observasi respons atlet. Penelitian ini menghasilkan media untuk pembelajaran teknik dasar bulu tangkis berbasis multimedia yang dikemas dalam CD dan disertakan buku petunjuk penggunaan. Teknik dasar bulu tangkis tersebut, yaitu: (1) bentuk-bentuk pegangan raket, (2) macam-macam servis, (3) macam-macam pukulan dari atas, dan (4) macammacam pukulan dari bawah.
\end{abstract}

Kata Kunci: pengembangan, teknik dasar bulu tangkis, multimedia, atlet usia 11 dan 12 tahun

\section{DEVELOPMENT FOR LEARNING THE BASIC TECHNIQUES OF BADMINTON BASED ON MULTIMEDIA TO ATHLETES AGED OF 11 AND 12}

\begin{abstract}
This research aimed to produce a media for learning the basic techniques of badminton based multimedia. The research and development was conducted by the following steps: (1) the introduction study phase, (2) validation of experts, (3) testing product, and, (4) creating the final product. Instruments for collecting the data were: (1) the first product validation, (2) the questionnaire observation for coach and expert, and (3) observation sheet response for athletes. This research produced a media for learning the basic technique of badminton based on multimedia that was packaged in a CD and user's guide included. The basic techniques are: (1) the forms of racket grip, (2) services, (3) a variety of overhead stroke, and (4) a variety of underhand stroke.
\end{abstract}

Keywords: development, the basic techniques of badminton, multimedia, athletes at the age of 11 and 12 years old.

How to Cite: Putra, G., \& Sugiyanto, F. (2016). Pengembangan pembelajaran teknik dasar bulu tangkis berbasis multimedia pada atlet usia 11 dan 12 tahun. Jurnal Keolahragaan, 4(2), 175 - 185.

doi:http://dx.doi.org/10.21831/jk.v4i2.10893

Permalink/DOI: http://dx.doi.org/10.21831/jk.v4i2.10893 


\section{PENDAHULUAN}

Olahraga bulu tangkis merupakan salah satu olahraga terpopuler di Indonesia dari dahulu sampai sekarang. Bagi bangsa Indonesia olahraga bulu tangkis merupakan olahraga untuk semua lapisan masyarakat, karena dapat dimainkan oleh anak-anak, dewasa, laki-laki atau perempuan. Hal itu baik yang tujuannya untuk rekreasi dan hiburan, menjaga kesehatan dan kebugaran, maupun untuk meraih prestasi.

Agar seseorang dapat bermain bulu tangkis dengan baik, setiap individu harus mampu memukul kok dari atas maupun dari bawah. Adapun jenis-jenis pukulan yang harus dikuasai antara lain service, lob, dropshot, smash, netting, underhand, dan drive. Semua jenis pukulan tersebut harus dilakukan dengan menggunakan grip dan footwork yang benar (Alhusin, 2007, p. 24).

Tahap awal untuk menguasai teknikteknik bulu tangkis adalah dimulai dengan pengenalan. Proses pengenalan teknik dasar dapat dilakukan dengan memberikan penjelasan secara langsung yang dilanjuti dengan contoh gerakan di hadapan atlet atau dengan memanfaatkan media ajar sebagai sarana pembelajaran, seperti memberikan buku bacaan/pengetahuan mengenai bulu tangkis, menonton video-video latihan, melihat gambar/poster (urutan-urutan pelaksanaan) dan sebagainya. Tahap berikutnya untuk menguasai teknik-teknik bulu tangkis yaitu dengan mencoba melakukan/memeragakan teknik yang diajarkan secara berulangulang (tahap latihan).

Proses pengenalan teknik dasar yang dipaparkan dapat disajikan secara bersamaan tanpa harus terpisah-pisah. Penggabungan tersebut dapat dilakukan dengan menggunakan software (perangkat lunak) macromedia flash atau microsoft power point. Penggabungan mediamedia tersebut dikenal dengan produk akhir berupa multimedia interaktif (Sofyan \& Purwanto, 2008 , p. 8). Dalam pelaksanaannya, penggunaan multimedia interkatif dengan menggunakan macromedia flash sebagai media pembelajaran jauh lebih baik daripada menggunakan microsoft power point (Sahayu, 2013, p. 10).

Klub-klub yang peneliti amati, proses pengenalan teknik dasar bulu tangkis ke atlet yaitu dengan cara memberikan penjelasan secara langsung yang dilanjuti dengan contoh gerakan. Gerakan-gerakan teknik pada bulu tangkis berlangsung cepat antara fase persiapan, pelaksanaan, dan lanjutan. Keterbatasan indra penglihatan dari atlet untuk mencerna informasi berupa peragaan gerak (teknik), selama ini pelatih menyiasati dengan melakukan gerak secara perlahan. Meskipun demikian, dengan cara seperti ini terdapat perbedaan antara gerakan sebenarnya dan gerakan yang dibuat lambat sebagai cara mencontohkan gerakan ke atlet pada proses pengenalan teknik. Contohnya, shuttlecock (kok) sering tidak kena atau tidak sampai tujuan saat memeragakan teknik pukulan ke atlet (dengan cara memperlambat gerak).

Sadiman (Winarno, et al, 2009, p. 2) berpendapat mengenai kegunaan dari media pembelajaran, salah satunya dapat mengatasi keterbatasan ruang, waktu, dan daya indra, seperti gerakan yang terlalu cepat bisa diperlambat dengan bantuan timelapse, gerakan yang terlalu lambat bisa dibantu dengan highspeed photography. Rangkaian gerakan teknik dasar yang begitu cepat dalam hitungan detik, dengan timelapse bisa diperlambat sehingga potongan film/video gerakan teknik yang akan diajarkan dapat terlihat dengan jelas, menarik tanpa merubah gerakan bentuk aslinya. Dengan penggunaan media pembelajaran, problem-problem saat pengenalan teknik bisa teratasi. Media pembelajaran ini akan berfungsi sebagai solusi, apabila klub-klub bulu tangkis sudah menggunakan komputer sebagai sarana untuk pengenalan teknik bulu tangkis. Meskipun demikian, klub-klub yang peneliti amati belum memanfaatkan komputer sebagai sarana pembelajaran.

Undang-Undang RI Nomor 3 Tahun 2005 tentang Sistem Keolahragaan Nasional, Pasal 20 Ayat 5e diambil dari Bappenas (2010) yang berbunyi "untuk memajukan olahraga prestasi, pemerintah, pemerintahan daerah, dan/atau masyarakat dapat mengembangkan: prasarana dan sarana olahraga prestasi." Yousif \& Yeh (2011, pp. 61-67) telah mengembangkan (memperbarui) software mesin pelontar yang diberi nama CATIA, alat ini mampu mewakli laju kok sebenarnya saat latihan manual dengan manusia/pelatih. Hal ini dapat diartikan ada atau tidak ada pelatih di lapangan, atlet masih bisa berlatih pukulan dengan pelaku drill (pelontar kok) dari alat CATIA.

Penjelasan tersebut melatarbelakangi pengembangan media pembelajaran teknik dasar bulu tangkis yang berbasiskan multimedia. Konsep kemudahan untuk mencerna materi (kognitif) agar dapat diingat dalam waktu yang lama dan kemudahan penggunaan (pengoperasian) multimedia adalah landasan utama dalam pengembangan ini. Episodik dan semantik ada- 
lah acuan untuk menyusun isi materi pembelajaran dalam multimedia agar mudah dicerna oleh memori atlet/otak (Sudarmawan \& Arius, 2007, p. 30). Semakin mudah informasi untuk dicerna, semakin mudah atlet untuk memeragakan gerakan/ teknik yang baru saja dipelajarinya. Pemanfaatan link dan tool yang ada pada multimedia serta buku petunjuk pengoperasiannya adalah cara yang diterapkan peneliti untuk memudahkan penggunaan (menjalankan) media pembelajaran. Dengan konsep kemudahan ini diharapkan hasil dari pengembangan ini mampu menciptakan atlet-atlet pemula berbakat lebih banyak lagi.

Pembinaan olahraga di tingkat klub atau sekolah, pada umumnya dimulai sejak periode usia dini antara usia 6-12 tahun. Eksistensinya sebagai lapisan pembinaan yang berperan untuk melanggengkan proses regenerasi menjadi sangat penting, lebih-lebih karena klub dan sekolah merupakan pusat awal pembinaan atletatlet usia dini dan menjadikan salah satu strategi paling mendasar dalam upaya meningkatkan prestasi olahraga (Purnama, 2013, pp. 3435). Pada usia ini, anak dianjurkan untuk mengembangkan gerak dasar dan keterampilan yang luas serta pengembangan dasar kemampuan biomotor untuk mencapai kebugaran yang baik. Oleh karena itu latihan pada tahap multilateral perlu berisi berbagai gerak dasar dan gerak dasar keterampilan cabang olahraga. Atlet multilateral pada dasarnya adalah atlet yang masih sangat muda. Oleh karena itu pemberian beban latihan pada tahap ini tidak memerlukan frekuensi yang banyak dalam satu minggu. Frekuensi latihan untuk atlet multilateral hanya berkisar tiga kali dalam seminggu. Pada akhir usia masa ini, latihan mingguan terdiri atas dua sesi yang mengandung cabang olahraga potensial bagi atlet dari tiga kali per minggu. Latihan yang seperti ini cocok untuk anak usia akhir dari fase multilateral (11-12 tahun). Pada usia ini atlet pemula masih dalam fase multilateral tetapi sudah mulai menjalani latihan potensi khusus (Lumintuarso, 2013, pp. 7-29).

Didasarkan pertimbangan karakteristik anak, melatih atlet usia 11 dan 12 tahun sudah bisa diarahkan ke gerak-gerak dasar kecabangan yang digelutinya. Meskipun demikian, gerakan-gerakan dasar bukan berarti dihilangkan secara keseluruhan, tetapi sudah mulai dikurangkan. Dengan kata lain dapat disimpulkan, makin ke penghujung usia multilateral makin sedikit gerak dasar diberikan ke anak dan semakin banyak gerakan-gerakan dasar kecabangan (olahraga) diberikan, bagitu juga sebaliknya.

Pada praktiknya, usia bukan suatu hal yang menjadi patokan untuk memberikan batasan-batasan latihan kepada anak (atlet). Pada klub-klub yang peneliti amati, pembatasan atau tingkatan-tingkatan latihan yang diberikan ke atlet-altetnya bukan berdasarkan kesiapan fisik dan mental (emosi, akal, dan sebagainya), tetapi teori dan tingkatan latihan yang diberikan ke anak berdasarkan kemampuannya menguasai bulu tangkis itu sendiri, walaupun usia masih terhitung muda. Tidak sedikit atlet yang ada di Kabupaten Sleman berasal dari pembinaan seperti ini. Secara usia masih muda, secara pemberian latihan (fisik, teknik, dan taktik) sudah seperti atlet remaja dan dewasa.

Atlet memiliki kemampuan mencerna dan daya tangkap yang berbeda-beda antara satu atlet dengan atlet yang lainnya. Apabila cara lama dipergunakan seperti penjelasan di awal bab ini, atlet yang memiliki daya tangkap rendah, secara otomatis atlet tidak memiliki peluang untuk mengulang dan mendengarkan kembali apa yang disampaikan oleh pelatih. Meskipun demikian, apabila pembelajaran menggunakan multimedia, masalah yang seperti ini bisa teratasi. Karena pelatih bisa mengulang materi yang sama ke atletnya, atlet mampu menguasai materi serta contoh pelaksanaan teknik dasar secara detail

Pemanfaatan video yang ada pada multimedia sebagai bahan pembelajaran teknik bulu tangkis sangat berguna. Hal ini akan terasa berguna jika pelatih tidak memiliki teknik atau kemampuan memberikan contoh gerakan secara baik sebagaimana yang dijelaskan pada paragraf-paragraf sebelumnya. Pemanfaatan media sebagai media pembelajaran juga dapat berguna untuk menarik minat atlet dan menjaga agar minatnya selalu tinggi. Dengan media ini pelatih bisa mengambil gambar dan video dari seorang pemain saat latihan berlangsung. Meminta pemain yang baik secara teknik agar memeragakan satu demi satu, step demi step teknik yang harus dilakukan, serta cara yang benar untuk melakukan gerakan dari teknik yang akan dipelajari oleh atlet.

\section{Teknik Dasar Bulu Tangkis}

Pada permainan bulu tangkis ada beberapa teknik pukulan yang harus dikuasai. Dinata (2006, p. 1) mengemukakan ada beberapa jenis pukulan yang harus dikuasai seperti service, lob, dropshot, smash, netting, underhand, dan 
drive. Semua jenis pukulan tersebut harus dilakukan dengan menggunakan grip dan footwork yang benar.

Teknik dasar yang pengembang uraikan di atas merupakan hasil dari pengkajian dengan mempertimbangkan efektif, efisien, dan kemudahan gerak. Teknik dasar pada bulu tangkis terdiri atas; (1) pegangan raket yang terdiri atas american grip, forehand grip, backhand grip, dan combination grip, (2) service yang terdiri atas short service forehand, long service forehand, dan short service backhand, (3) pukulan dari atas (overhead stroke) yang terdiri atas overhead lob forehand dan overhead drop forehand, (4) pukulan dari bawah (underhand stroke) yang terdiri atas underhand lob forehand, netting forehand, underhand lob backhand, dan netting backhand. Teknik-teknik yang belum tersebutkan pada pembahasan di atas tergabung dalam teknik lanjutan dan teknik prestasi.

\section{Hakikat Media Pembelajaran}

Menurut Smaldino, Lowther, \& Russell (2008, p. 6) kata media pembelajaran berasal dari bahasa Latin medium yang berarti tengah, perantara, atau pengantar. Media adalah “... anything that carries information between a sources and receiver." Dapat diartikan bahwa media merupakan pembawa informasi dari sumber ke penerima. Media adalah alat informasi dan sumber informasi baik berupa alat elektronik maupun nonelektronik yang dapat dijadikan sarana penyampaian pesan dalam berkomunikasi.

Media pembelajaran memiliki banyak jenis dan mempunyai karakter yang berbeda sesuai dengan fungsi dan pemanfaatannya masing-masing. Penggunaan media pembelajaran yang disarankan haruslah media yang sesuai dengan strategi, tujuan pembelajaran dan karakterisitik atlet secara psikologis. Levi dan Levie (Arsyad 2011, p. 9) menerangkan “... stimulus visual membuahkan hasil belajar yang lebih baik untuk tugas-tugas seperti mengingat, mengenali, mengingat kembali, dan menghubung-menghubungkan fakta dan konsep."

Dalam proses pembelajaran teknik dasar bulu tangkis seperti mengenali, mengingat, dan melakukannya untuk berulang kali secara terusmenerus dengan benar sebenarnya tidak harus selalu dibimbing oleh pelatih untuk membenarkan berulang-ulang. Hal ini bisa terjadi apabila media yang digunakan untuk pembelajaran tepat. Multimedia yang dikembangkan oleh peneliti bisa menjadi jawabannya, karena media ini dibuat untuk menjelaskan teknik secara bertahap dan mengalir dari umum ke khusus. Untuk memberikan kesan agar proses mengenali dan mengingat terjadi, tentu harus ada pengalih perhatian agar perhatian atlet pengguna tetap fokus dan tertarik untuk mempelajarinya. Dalam media yang dikembangkan, pengembangan menggunakan atlet berusia 12 tahun yang selalu menjadi langganan juara di kelompok umurnya. Hal ini bisa menjadi daya tarik tersendiri agar atlet pengguna tertarik untuk mempelajari teknik dasar melalui media ini, selain juga didukung dengan berbagai aspek penunjang yang ada di multimedia.

\section{Multimedia}

Multimedia berasal dari dua kata, yaitu multi dan media. Multi berarti banyak dan media biasa diartikan alat untuk menyampaikan atau membuat sesuatu, perantaraan, alat pengantar, suatu bentuk komunikasi seperti surat kabar, majalah, atau televisi (Ariyus, 2009, p. 2). Di sisi lain, Hofstetter (Sofyan \& Purwanto, 2008, p. 2) berpendapat multimedia adalah pemanfaatan komputer untuk menggabungkan teks, grafik, audio, gambar bergerak (video dan animasi) dengan link dan tool yang memungkinkan pemakai melakukan navigasi, berinteraksi, berkreasi, dan berkomunikasi.

Dalam defenisi di atas terkandung empat komponen penting mutimedia. Pertama, harus ada komputer yang mengkoordisasikan apa yang dilihat dan didengar, yang berinteraksi dengan pengguna. Kedua, harus ada link yang menggabungkan pengguna dengan informasi. Ketiga, harus ada alat navigasi yang memandu pengguna, menjelajah jaringan informasi yang saling terhubung. Keempat, multimedia menyediakan tempat kepada pengguna untuk mengumpulkan, memroses, dan mengombinasikan informasi dan ide pengguna sendiri. Jika salah satu komponen tidak ada, bukan multimedia dalam arti luas namanya. Misalnya, jika tidak ada komputer untuk berinteraksi, itu namanya media campuran, bukan multimedia. Jika tidak ada link yang menghadirkan sebuah struktur dan dimensi, namanya rak buku, bukan multimedia. Kalau tidak ada alat navigasi yang memungkinkan pengguna memilih jalannya suatu tindakan, itu namanya film, bukan multimedia. Demikian juga jika pengguna tidak mempunyai ruang untuk berkreasi dan menyumbangkan ide sendiri, namanya televisi, bukan multimedia (Suyanto, 2005, p. 20). 


\section{Multimedia dalam Olahraga}

Ariyus (2009, p. 2) multimedia berasal dari dua kata, yaitu multi dan media. Multi berarti banyak dan media biasa diartikan alat untuk menyampaikan atau membuat sesuatu, perantaraan, alat pengantar, suatu bentuk komunikasi seperti surat kabar, majalah, atau televisi. Hofstetter (Sofyan \& Purwanto, 2008, p.2) berpendapat multimedia adalah pemanfaatan komputer untuk menggabungkan teks, grafik, audio, gambar bergerak (video dan animasi) dengan menggabungkan link dan tool yang memungkinkan pemakai melakukan navigasi, berinteraksi, berkreasi, dan berkomunikasi.

Pada awal munculnya teknologi komputerisasi, keterbatasan SDM merupakan faktor utama yang menyebabkan terhambatnya interaksi antara manusia dan komputer. Meskipun demikian, faktanya sekarang, anak usia 3 tahun saja sudah bisa mengoperasikannya salah satunya adalah memainkan game. Hal ini bisa terlihat mudah dilakukan karena banyak hal pendukung yang ada dalam multimedia, seperti gambar, suara, teks, dan grafik (Sudarmawan \& Ariyus, 2007, p. 5).

Multimedia adalah salah satu media yang digunakan dalam olahraga sebagai media pembelajaran. Media pembelajaran dalam dunia olahraga ini diartikan sebagai alat yang mampu menjembatani penyampaian pesan dari pelatih ke atlet, agar atlet mampu memahami isi pesan yang berwujud simbol verbal dan visual dengan lebih baik. Pada proses pembelajaran, media pembelajaran dianggap penting karena mampu untuk mengurangi atau menghilangkan hambatan komunikasi atau pesan yang kurang atau tidak tersampaikan dengan baik karena pemberi pesan atau penerima pesan terdapat masalah dalam komunikasinya. Kelebihan multimedia adalah menarik indra dan menarik minat karena merupakan gabungan antara pandangan, suara, dan gerakan. Lembaga riset dan penerbitan komputer, Computer Technology Reseach (CTR) menyatakan bahwa orang hanya mampu mengingat $20 \%$ dari yang dilihat dan $30 \%$ dari yang didengar. Meskipun demikian, orang dapat mengingat $50 \%$ dari yang dilihat dan didengar, dan dapat mengingat $80 \%$ dari yang dilihat, didengar, dan dilakukan sekaligus (Suyanto, 2004, pp.30-31).

\section{Manfaat Media Pembelajaran}

Proses pembelajaran memegang penting dalam menghasilkan atau menciptakan kualitas anak latih. Oleh karena itu, hal utama yang seyogyanya mendapatkan perhatian lebih serius oleh pelatih adalah menciptakan proses pembelajaran saat latihan yang berkualitas. Hal itu disebabkan oleh proses pembelajaran yang berkualitas memiliki pengaruh yang sangat signifikan dalam menghasilkan anak latih yang berkualitas. Untuk menghasilkan proses pembelajaran yang berkualitas, terdapat banyak aspek yang turut memengaruhinya. Winarno, et al (2009, p. 2) aspek tersebut antara lain pelatih yang profesional dan berkualitas, penggunaan metode latih yang menarik dan bervariasi, perilaku belajar anak latih yang positif, kondisi dan suasana belajar (latihan) yang kondusif untuk latihan dan penggunaan media pembelajaran yang tepat dalam mendukung proses belajar itu sendiri.

Manfaat media pembelajaran menurut Mustikasari (2008, p.?) adalah: (1) penyampaian materi pembelajaran dapat diseragamkan, (2) proses pembelajaran menjadi lebih jelas dan menarik, (3) proses pembelajaran menjadi lebih interaktif, (4) efisiensi dalam waktu dan tenaga, (5) meningkatkan kualitas hasil belajar siswa (atlet), (6) media memungkinkan proses belajar dapat dilakukan dimana saja dan kapan saja, (7) media dapat menimbulkan sikap positif siswa (atlet) terhadap materi dan proses belajar, dan (8) mengubah peran guru (pelatih) ke arah yang lebih positif dan produktif.

Sadiman (Winarno, et al, 2009, pp. 2-3) berpendapat mengenai kegunaan media pembelajaran sebagai berikut: (1) memperjelas penyajian pesan agar tidak terlalu bersifat verbalistis, (2) penggunaan media pembelajaran pada tahap orientasi pembelajaran akan sangat membantu keefektivan proses pembelajaran dan penyampaian pesan dan isi pelajaran, (3) penggunaan media dapat menjadikan proses pembelajaran menjadi lebih interaktif, (4) penggunaan media pembelajaran secara tepat dan bervariasi dapat mengatasi sikap pasif peserta didik, dan (5) mengatasi keterbatasan ruang, waktu, dan, daya indra, seperti: (a) objek yang terlalu besar bisa digantikan dengan realita, gambar, film bingkai, film atau model, (b) objek yang terlalu kecil dapat dibantu dengan proyektor mikro, film bingkai, film atau gambar, (c) gerak yang terlalu cepat atau terlalu lambat dapat dibantu dengan timelapse, atau highspeed photography, 
(d) kejadian atau peristiwa yang terjadi di masa lalu bisa ditampilkan melalui rekaman film, video, film bingkai, atau film, (e) objek yang terlalu kompleks (misal mesin-mesinan) dapat disajikan dengan model, atau diagram, (f) konsep yang terlalu luas (gunung berapi, gempa bumi, iklim, dan lain-lain) dapat divisualisasikan dalam bentuk film, film bingkai, gambar, dan lain-lain.

\section{Prosedur Pengembangan Media Pembelajaran}

Phillips (Winarno, et al, 2009, p. 23) mengutarakan prosedur pengembangan multimedia pembelajaran dengan konsep dasar interaktif dilakukan melalui empat tahapan pengembangan. Empat tahap pengembangan tersebut meliputi: (a) desain, (b) development, (c) evaluation,dan (d) implementation. Keempat tahapan ini merupakan siklus yang terus berjalan secara kontinu selama pengembangan multimedia interaktif itu terus berlangsung. Lebih jelasnya dapat dilihat pada gambar dan penjelasan berikut.

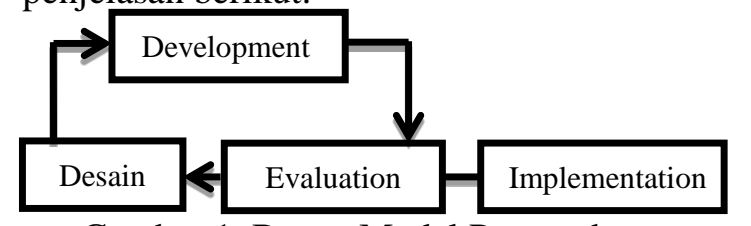

Gambar 1. Bagan Model Pengembangan Multimedia

Sumber: Phillips (Winarno, et al, 2009, p. 23)

\section{Teori Belajar Kognitif}

Teori belajar kognitif muncul sebagai kritik terhadap teori behavioristik yang memandang siswa dan pelakunya sebagai hasil dari respons terhadap stimulus dari lingkungannya. Menurut Wittrock (Woolfolk, 2004, p. 236) teori belajar kognitif memandang anak sebagai "sumber rencana, perhatian, tujuan, gagasan, ingatan, dan emosi yang secara aktif digunakan untuk memperhatikan, menyeleksi, dan menentukan makna dari stimulus dan pengetahuan dari pengalaman."

Teori kognitif ini memandang seseorang sebagai pelajar yang aktif, yang berusaha mencari pengalaman, mencari informasi untuk menyelesaikan masalah, dan mengorganisasikan apa yang telah diketahui untuk mencapai pengetahuan baru. Lebih lanjut (Woolfolk, 2004, p 236) menjelaskan, meskipun secara pasif dipengaruhi lingkungan, anak (atlet) akan aktif memilih, memutuskan, mempraktikkan, memperhatikan, mengabaikan, dan membuat banyak respons lain untuk mengejar tujuan. Pendekatan kognitif menjelaskan bahwa satu elemen yang paling penting dalam pembelajaran adalah apa yang seseorang bawa, yaitu pengetahuan dalam situasi belajar. Apa yang telah diketahui menentukan seberapa luasnya apa yang akan dipelajari, diingat, dan dilupakan.

\section{Teori Belajar Kognitif Menurut Beberapa Ahli}

Teori Perkembangan Piaget

Menurut Piaget (Zanden \& Pace, 1984, pp.164-165) perkembangan kognitif merupakan suatu proses genetik, yaitu proses yang didasarkan atas mekanisme biologis perkembangan saraf. Semakin bertambah umur seseorang, semakin kompleks susunan saraf dan makin meningkat pula kemampuannya. Dalam perkembangannya, individu akan selalu berinteraksi dengan lingkungannya yang menimbulkan persepsi baru tentang dunia dan organisasi pengetahuan baru. Pengetahuan baru berinteraksi dengan struktur kognitif yang telah ada sebelumnya, sehingga mengubah struktur dan membuatnya lebih memadai. Dalam interaksi dengan lingkungannya, individu mengubah lingkungan, dan pada gilirannya individu harus mengubah dirinya untuk beradaptasi dengan kondisi yang telah berubah. Struktur kognitif terbentuk melalui proses transformasi yang terus-menerus.

\section{Teori Kognitif Bruner}

Menurut Bruner (Ismail, tahun?, p.?) belajar melibatkan tiga proses kognitif yang berlangsung hampir bersamaan, yaitu: (1) tahap informasi (tahap penerimaan materi) (2) tahap transformasi (tahap pengubahan materi), dan (3) evaluasi (tahap penilaian materi). Memperoleh informasi baru merupakan penghalusan dari informasi sebelumnya yang dimiliki seseorang, atau informasi dapat berlawanan dengan informasi sebelumnya yang dimiliki seseorang. Dalam transforamsi, informasi itu harus dianalisis, diubah atau ditransformasi ke bentuk yang lebih abstrak atau konseptual agar dapat digunakan untuk hal-hal yang lebih luas. Tahap evaluasi (tahap penilaian materi) dinilai seberapa besar pengetahuan yang diproleh dan ditransformasikan itu dapat dimanfaatkan untuk memahami gejala-gejala lain.

Teori Belajar Bermakna Ausubel 
Menurut Ausubel (Slavin, 1991, p. 162) belajar bermakna merupakan suatu proses mengaitkan informasi baru pada konsep-konsep relevan yang terdapat dalam struktur kognitif seseorang. Informasi baru diasimilasikan dan dihubungkan dengan pengetahuan yang dimiliki dalam struktur kognitif seseorang.

\section{Aplikasi Teori Kognitif dalam Pembelajaran}

Hakikat belajar menurut teori kognitif dijelaskan sebagai suatu aktivitas belajar yang berkaitan dengan penataan informasi, reorganisasi perseptual, dan proses internal. Dalam merumuskan tujuan pembelajaran, mengembangkan strategi dan tujuan pembelajaran. Kebebasan dan keterlibatan siswa/atlet secara aktif dalam proses belajar sengat diperhitungkan, agar belajar lebih bermakna bagi siswa/atlet.

Penerapan teori kognitif juga terlihat pada rancangan kegiatan pembelajaran yang dikemukakan secara berbeda oleh beberapa tokoh sesuai dengan sudut pandang masing-masing. Para tokoh aliran kognitif, baik Bruner, Ausubel, maupun Piaget, secara umum memiliki pandangan yang sama yaitu mementingkan keterlibatan siswa/atlet secara aktif dalam belajar. Menurut Piaget, hanya dengan mengaktifkan siswa/atlet secara optimal proses asimilasi, akomodasi pengetahuan, dan pengalaman dapat terjadi dengan baik. Sementara itu, Bruner lebih banyak memberikan kebebasan kepada siswa/atlet untuk belajar sendiri melalui aktivitas menemukan (discovery). Cara demikian akan mengarahkan siswa/atlet pada bentuk belajar induktif, yang menuntut banyak dilakukan pengulangan. Hal ini tercermin dari model kurikulum spiral yang dikemukakannya. Ausubel lebih mementingkan struktur kognitif. Hal ini tampak dari konsepsinya mengenai advance organizer sebagai kerangka konseptual tentang isi pelajaran yang akan dipelajari siswa/atlet.

\section{METODE}

Penelitian ini menggunakan metode penelitian dan pengembangan, bertujuan untuk mengembangkan media pembelajaran yang bertujuan untuk mengenalkan teknik dasar bulu tangkis dengan berbasiskan multimedia. Penelitian dan pengembangan akan menghasilkan suatu produk yang berkualitas dan lebih memungkinkan untuk diterapkan sebagai media pembelajaran di lapangan dalam bentuk softwere yang dikemas dalam $\mathrm{CD}$ beserta buku petunjuk penggunaan.

\section{Prosedur Pengembangan}

Penelitian pengembangan yang mengacu model pengembangan dari Borg dan Gall (2003, p.570) ada sepuluh tahapan yang dijalani, yaitu: (1) studi pendahuluan (studi lapangan dan pustaka), (2) perencanaan, (3) pengembangan produk awal, (4) uji coba awal, (5) revisi untuk menyusun produk utama, (6) uji coba lapangan utama, (7) revisi untuk menyusun produk operasional, (8) uji coba produk operasional, (9) revisi produk final, dan (10) diseminasi dan implementasi produk hasil pengembangan.

\section{Tempat dan Waktu Pengembangan}

Penelitian pengembangan ini dilaksanakan pada PB. STIM YKPN Sleman dan PB. Pancing Sembada Sleman. Dilakukan dari bulan Maret 2014 sampai dengan bulan April 2014, sehingga dapat dikatakan bahwa lama penelitian dari proses awal sampai proses akhir adalah dua bulan.

\section{Desain Uji Coba}

Uji coba poduk dilakukan untuk mendapatkan data yang akan digunakan untuk mengetahui kelemahan-kelemahan produk yang dikembangkan sebagai dasar untuk melakukan revisi produk yang berupa media pembelajaran keterampilan dasar bulu tangkis yang berbasis multimedia untuk anak-anak usia 11 dan 12 tahun. Uji coba produk dalam penelititan ini dilakukan dalam dua tahap, yaitu: (1) uji coba lapangan kelompok kecil, dan (2) uji coba lapangan kelompok besar.

\section{Subjek Coba}

Subjek coba dalam penelitian pengembangan ini adalah atlet dengan usia 1112 tahun. Uji coba kelompok kecil dilaksakan di PB. STIM YKPN Sleman 4 atlet dan uji coba kelompok besar dilaksanakan di PB. Pancing Sembada Sleman 10 atlet.

\section{Instrumen Pengumpulan Data}

Teknik pengumpulan data pertama yang digunakan yaitu teknik komunikasi langsung dengan menggunakan instrumen wawancara sebagai alat pengumpulan data. Definisi dari teknik komunikasi langsung adalah mekanisme pengumpulan data yang dilakukan melalui kontak atau hubungan pribadi dalam bentuk tatap muka (face to face relationship) antara pengumpulan data dan responden. Menurut (Riduwan, 2004, p. 74) wawancara adalah suatu 
cara pengumpulan data yang digunakan untuk memperoleh informasi langsung dari sumbernya. Wawancara ini digunakan untuk mengetahui hal-hal dari responden secara mendalam serta jumlah responden sedikit. Ada beberapa faktor yang akan memengaruhi arus informasi dalam wawancara, yaitu pewawancara, responden, pedoman wawancara, dan situasi wawancara. Butir-butir pertanyaan meliputi: (1) seperti apa kegiatan saat pemberian/penjelasan materi bulu tangkis, (2) lama waktu pembelajaran (pengenalan) teknik dasar bulu tangkis, (3) media apa yang digunakan saat penjelasan teknik dasar, (4) batasan usia untuk pengenalan berbagai teknik berdasarkan tingkat kesulitan, (5) kendala yang dialami saat pembelajaran (pengenalan teknik).

Teknik pengumpulan data berikutnya berupa penyiapan instrumen yang akan digunakan untuk mengumpulkan data yaitu berupa instrumen penilaian untuk menilai produk yang telah dikembangkan baik dari aspek instruksional, aspek isi, aspek tampilan, dan aspek manfaat. Instrumen yang dikembangkan dan digunakan dalam penelitian ini meliputi: (a) validasi produk awal, (b) angket observasi untuk pelatih dan ahli materi, dan (c) lembar observasi respons atlet.

\section{Teknik Analisis Data}

Teknik analisis data yang dilakukan dalam penelitian ini yaitu analisis deskriptif kuantitatif dan analisis deskriptif kualitatif. Analisis deskriptif kuantitatif dilakukan untuk menganalisis data-data berikut: (1) data skala nilai hasil penilaian terhadap isi materi teknik dasar bulu tangkis pada media pembelajaran, (2) data hasil observasi ahli multimedia terhadap kualitas media pembelajaran, (3) data hasil observasi pelatih dan ahli materi pada media pembelajaran, dan (4) data observasi respons atlet. Sementara analisis deskriptif kualitatif dilakukan terhadap: (1) data hasil wawancara dengan pelatih saat studi pendahuluan, (2) data kekurangan dan masukan terhadap media pembelajaran teknik dasar bulu tangkis sebelum uji coba maupun setelah uji coba di lapangan.

\section{HASIL DAN PEMBAHASAN}

\section{Validasi Ahli}

Data yang diperoleh merupakan hasil penilaian ahli materi (bulu tangkis) dan ahli media terhadap produk yang dikembangkan disertai saran untuk perbaikan. Deskripsi data dapat dilihat pada Tabel 1 dan 2.

Dari hasil penilaian skala nilai (rating scale) yang diberikan pakar/ahli terhadap revisi produk awal sebelum diujicobakan di lapangan, para ahli materi: (1) Suharjana (ahli bulu tangkis) dan (2) Ali Muhtadi (ahli media).

Suharjana, selaku ahli materi memberikan masukan dan saran untuk perbaikan materi yang dikembangkan dalam media pembelajaran. Masukan-masukan tersebut meliputi: (1) suara pengisi lebih dikuatkan (volume), (2) penyajian materi dipotong-potong sesuai dengan materi latihan yang disampaikan dalam media, dan (3) cover CD diberi gambar untuk memperjelas isi dari CD media pembelajaran.

Tabel 1. Penilaian Ahli Bulu Tangkis terhadap Produk

\begin{tabular}{ccc}
\hline No. & Responden & Jumlah Skor Penilaian \\
\hline 1. & Suharjana & 59 \\
\hline
\end{tabular}

Jumlah skor ideal/kriterium untuk aspek isi materi bulu tangkis (seandainya semua menjawab SS) $=4 \times 17 \times 1=68 ; 4=$ skor tertinggi tiap butir, $17=$ jumlah butir pertanyaan, dan 1 = jumlah responden (Sugiyono, 2010, p. 137). Jumlah skor hasil pengumpulan data $=59$. Dengan demikian tingkat persetujuan ahli materi terhadap isi materi pada media pembelajaran teknik dasar bulu tangkis berbasis multimedia yaitu (59:68) x $100 \%=86,76 \%$ dari kriteria yang diharapkan $(100 \%)$. Hal ini secara kontinum dapat dibuat kategori sebagai berikut.

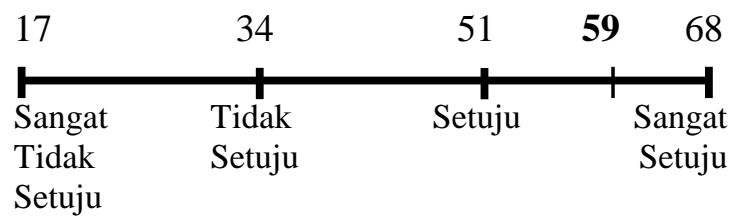

Dari perhitungan tersebut dapat disimpulkan, nilai 59 termasuk dalam kategori interval "setuju dan sangat setuju", tetapi lebih mendekati kriteria sangat setuju.

Ahli media dalam penelitian ini memberikan masukan dan saran untuk menyelaraskan antara media dan materi yang akan disampaikan serta elemen-elemen pendukung yang bisa dimanfaatkan untuk menunjang daya tarik dari media pembelajaran yang dikembangkan. Masukan tersebut "CD sebaiknya diberi cover, sehingga jika terlepas dari tempatnya masih jelas isi dari CD tersebut tentang apa." 
Setelah melakukan revisi terhadap produk awal, pengembang meminta kembali masukan serta penilain dari para pakar/ahli. Penilaian dari ahli materi berupa skala likert dengan rentang penilaian $1-4$. Nilai 1 berarti sangat tidak setuju, 2 berarti tidak setuju, 3 berarti setuju, dan 4 berarti sangat setuju. Dari hasil penilaian ahli materi ini, keseluruh materi baik itu dari aspek isi maupun aspek pembelajaran yang terkandung dalam media sudah memenuhi kriteria.

Tabel 2. Penilaian Ahli Media terhadap Produk

\begin{tabular}{ccc}
\hline No. & Responden & Jumlah Skor Penilaian \\
\hline 1. & Ali Muhtadi & 69 \\
\hline & Jumlah skor ideal/kriterium untuk aspek
\end{tabular}
tampilan media pembelajaran (seandainya semua menjawab SS) $=4 \times 19 \times 1=76 ; 4=$ skor tertinggi tiap butir, $19=$ jumlah butir pertanyaan, dan $1=$ jumlah responden (Sugiyono, 2010, p. 137). Jumlah skor hasil pengumpulan data $=$ 69. Dengan demikian tingkat persetujuan ahli media terhadap tampilan media pembelajaran pada media pembelajaran teknik dasar bulu tangkis berbasis multimedia yaitu $(69: 76) \mathrm{x}$ $100 \%=90,79 \%$ dari kriteria yang diharapkan $(100 \%)$. Hal ini secara kontinum dapat dibuat kategori sebagai berikut.

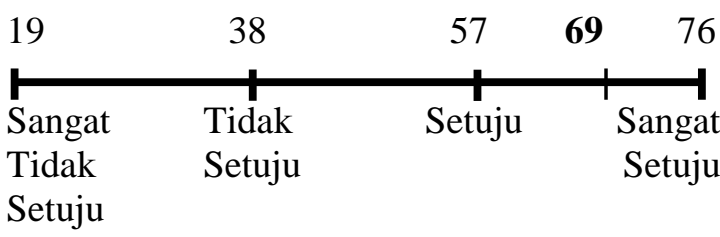

Dari perhitungan tersebut dapat disimpulkan, nilai 69 termasuk dalam kategori interval "setuju dan sangat setuju", tetapi lebih mendekati kriteria sangat setuju.

\section{Uji Coba Keleompok Kecil}

Setelah mendapatkan validasi dari para ahli terhadap produk awal media pembelajaran teknik dasar bulu tangkis berbasis multimedia, peneliti melakukan uji coba kelompok kecil di PB. STIM YKPN Sleman. Dari pelaksanaan uji coba ini, didapatkan data meliputi: (1) data hasil observasi media pembelajaran teknik dasar bulu tangkis berbasis multimedia untuk pembelajaran teknik dasar bulu tangkis, (2) data masukan dari pelatih terhadap produk media pembelajaran teknik dasar bulu tangkis berbasis multimedia, dan (3) data responden dari atlet terhadap produk media pembelajaran yang dikembangkan untuk pembelajaran teknik dasar bulu tangkis melalui multimedia. Adapun observer dalam uji coba kelompok keci ini adalah Uki Afresi dan Dedy Hendra Wahyudi. Observer merupakan pelatih bulu tangkis dari PB. STIM YKPN Sleman. Data-data tersebut dipaparkan sebagai berikut.

Tabel 3. Data Hasil Observasi Uji Coba Kelompok Kecil

\begin{tabular}{ccc}
\hline No. & Responden & Skor \\
\hline 1. & Pelatih 1 & 58 \\
2. & Pelatih 2 & 60 \\
3. & Ahli Materi & 63 \\
& Jumlah & $\mathbf{1 8 1}$ \\
\hline
\end{tabular}

Jumlah skor ideal/kriterium untuk hasil observasi uji coba kelompok kecil (seandainya semua menjawab SS) $=4 \times 18 \times 3=216 ; 4=$ skor tertinggi tiap butir, $18=$ jumlah butir pertanyaan, dan 3 = jumlah observer (Sugiyono, 2010, p. 137). Jumlah skor hasil pengumpulan data $=181$. Dengan demikian tingkat persetujuan ahli materi dan para pelatih terhadap produk yang dikembangkan yaitu media pembelajaran teknik dasar bulu tangkis berbasis multimedia yaitu (181:216) x $100 \%=83,80 \%$ dari kriteria yang diharapkan (100\%). Hal ini secara kontinum dapat dibuat kategori sebagai berikut.

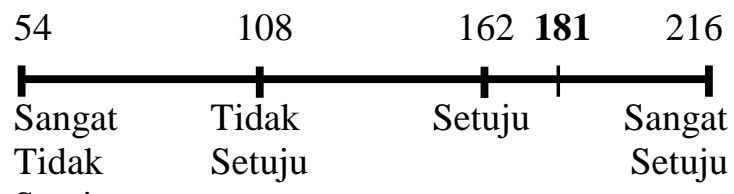

Setuju

Dari perhitungan dapat disimpulkan, nilai 181 termasuk dalam kategori interval "setuju dan sangat setuju", tetapi lebih mendekati kriteria setuju.

Tabel 4. Tabel Respons Atlet terhadap Produk Media Pembelajaran

\begin{tabular}{ccc}
\hline No. & Responden & Skor \\
\hline 1. & Atlet 1 & 36 \\
2. & Atlet 2 & 36 \\
3. & Atlet 3 & 36 \\
4. & Atlet 4 & 36 \\
& Jumlah Skor & $\mathbf{1 4 4}$ \\
\hline
\end{tabular}

Jumlah skor ideal/kriterium untuk jumlah nilai dari responden saat uji coba kelompok kecil (seandainya semua menjawab SS) $=4 \times 9$ x $4=144 ; 4=$ skor tertinggi tiap butir, $9=$ jumlah butir pertanyaan, dan $4=$ jumlah responden (Sugiyono, 2010, p. 137). Jumlah nilai hasil pengumpulan data $=144$. Dengan demikian tingkat persetujuan responden terhadap produk yang dikembangkan yaitu media pembelajaran teknik dasar bulu tangkis berbasis multimedia 
yaitu $(144: 144) \times 100 \%=100 \%$ dari kriteria yang diharapkan (100\%). Hal ini secara kontinum dapat dibuat kategori sebagai berikut.

\begin{tabular}{llcc}
36 & 72 & 108 & $\mathbf{1 4 4}$ \\
\hline Sangat & Tidak & Setuju & $\begin{array}{c}\text { Sangat } \\
\text { Tidak }\end{array}$ \\
Setuju & & Setuju
\end{tabular}

Setuju

Dari perhitungan tersebut dapat disimpulkan, nilai 144 termasuk dalam kategori "sangat setuju".

\section{Uji Coba Keleompok Besar}

Berdasarkan hasil uji coba kelompok kecil, media pembelajaran berbasis multimedia yang dikembangkan oleh peneliti layak untuk diujikan ke dalam kelompok yang lebih besar. Pada uji coba kelompok besar peneliti melakukan di PB. Pancing Sembada Sleman. Dari pelaksanaan uji coba ini, didapatkan data meliputi: (1) data hasil observasi media pembelajaran teknik dasar bulu tangkis berbasis multimedia untuk pembelajaran teknik dasar bulu tangkis, (2) data masukan dari pelatih terhadap produk media pembelajaran teknik dasar bulu tangkis berbasis multimedia, dan (3) data responden dari atlet terhadap produk media pembelajaran yang dikembangkan untuk pembelajaran teknik dasar bulu tangkis melalui multimedia. Adapun observer dalam uji coba kelompok besar ini adalah Taufik Yusuf dan Herlambang. Observer merupakan pelatih bulu tangkis dari PB. Pancing Sembada Sleman.. Data-data tersebut dipaparkan sebagai berikut.

Tabel 5. Data Hasil Observasi Uji Coba Kelompok Besar

\begin{tabular}{ccc}
\hline No. & Responden & SKor \\
\hline 1. & Pelatih 1 & 58 \\
2. & Pelatih 2 & 60 \\
3. & Ahli Materi & 63 \\
& Jumlah Skor & $\mathbf{1 8 3}$ \\
\hline
\end{tabular}

Jumlah skor ideal/kriterium untuk hasil observasi uji coba kelompok besar (seandainya semua menjawab SS) $=4 \times 18 \times 3=216 ; 4=$ skor tertinggi tiap butir, $18=$ jumlah butir pertanyaan, dan 3 = jumlah observer (Sugiyono, 2010, p. 137). Jumlah skor hasil pengumpulan data $=183$. Dengan demikian tingkat persetujuan ahli materi dan para pelatih terhadap produk yang dikembangkan yaitu media pembelajaran teknik dasar bulu tangkis berbasis multimedia yaitu $(183: 216) \times 100 \%=84,72 \%$ dari kriteria yang diharapkan (100\%). Hal ini secara kontinum dapat dibuat kategori sebagai berikut.

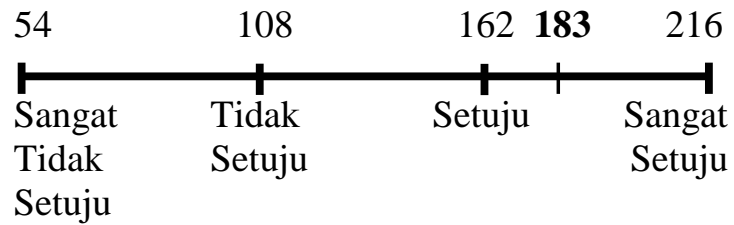

Dari perhitungan di atas dapat disimpulkan, nilai 183 termasuk dalam kategori interval "setuju dan sangat setuju", tetapi lebih mendekati kriteria setuju.

Tabel 4. Tabel Respons Atlet terhadap Produk Media Pembelajaran

\begin{tabular}{ccc}
\hline No. & Responden & Skor \\
\hline 1. & Atlet 1 & 32 \\
2. & Atlet 2 & 32 \\
3. & Atlet 3 & 36 \\
4. & Atlet 4 & 33 \\
5. & Atlet 5 & 36 \\
6. & Atlet 6 & 32 \\
7. & Atlet 7 & 33 \\
8. & Atlet 8 & 33 \\
9. & Atlet 9 & 34 \\
10. & Atlet 10 & 34 \\
& Jumlah Skor & $\mathbf{3 3 5}$ \\
\hline
\end{tabular}

Jumlah skor ideal/kriterium untuk jumlah nilai dari responden saat uji coba kelompok besar (seandainya semua menjawab SS) $=4 \times 9$ x $10=360 ; 4=$ skor tertinggi tiap butir, $9=$ jumlah butir pertanyaan, dan $10=$ jumlah responden (Sugiyono, 2010, p. 137). Jumlah nilai hasil pengumpulan data $=335$. Dengan demikian tingkat persetujuan responden terhadap produk yang dikembangkan yaitu media pembelajaran teknik dasar bulu tangkis berbasis multimedia yaitu $(335: 360) \times 100 \%=93,06$ $\%$ dari kriteria yang diharapkan (100\%). Hal ini secara kontinum dapat dibuat kategori sebagai berikut.

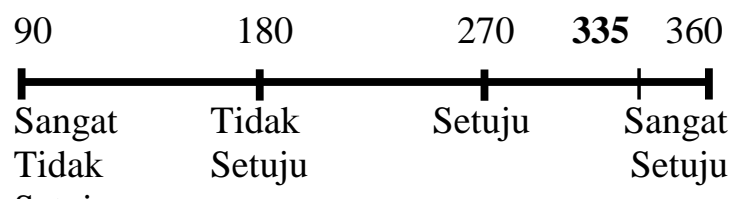

Setuju

Dari perhitungan tersebut dapat disimpulkan, nilai 335 termasuk dalam kategori "sangat setuju".

\section{SIMPULAN}

Berdasarkan hasil penilaian tingkat persetujuan para ahli dan pelatih terhadap media pembelajaran yang dikembangkan dapat disimpulkan bahwa media pembelajaran teknik dasar bulu tangkis dengan berbasiskan multimedia pada atlet usia 11 dan 12 tahun ini tergolong 
sangat setuju dari kriteria yang diharapkan. Produk dari penelitian pengembangan ini yaitu compact disc (CD) pembelajaran teknik dasar bulu tangkis berbasis multimedia beserta buku panduan penggunaan, terdiri atas beberapa materi teknik dasar, yaitu: (1) pegangan raket (grip) terdiri atas american grip, forehand grip, backhand grip type 1, backhand grip type 2, dan combination grip, (2) servis (service) terdiri atas short service forehand, long service forehand, dan short service backhand, (3) pukulan di atas kepala (overhead stroke) terdiri atas overhead lob forehand dan overhead drop forehand, dan (4) pukulan dari bawah (underhand stroke) terdiri atas netting forehand, netting backhand, underhand lob forehand, dan undehand drop backhand.

\section{DAFTAR PUSTAKA}

Alhusin, S. (2007). Gemar bermain bulutangkis. Surakarta: CV Seti Aji.

Ariyus, D. (2009). Keamanan multimedia ( $I^{s t}$ ed). Yogyakarta: CV Andi Offset.

Arsyad, A. (2011). Media pembelajaran. Jakarta: PT Raja Grafindo Persada.

Bappenas. (2010). Diambil pada tanggal 11 Januari 2011, dari http://kppo.bappenas.go.id/files/ringkasa n-eksekutifbidang-Olahraga\%2020102014.pdf.

Borg, W.R., \& Gall, M.D. (2003). Educational research and introduction $\left(7^{\text {th }} e d\right)$. New York: Longman Inc.

Dinata, M. (2006). Bulutangkis 2 (Rev. ed.). Ciputat: Cerdas Jaya.

Sahayu, W. (2013). Media pengajaran bahasa. Yogyakarta: Universitas Negeri Yogyakarta

Ismail, M. (22 Juni 2013). Teori belajar menurut jerome bruner. Diambil pada tanggal 12 Juli 2014, dari http://mohismaiel.blogspot.com/2013/06/ teori-belajar-menurut-jeromebruner.html.

Lumintuarso, R. (2013). Pembinaan multilateral bagi atlet pemula. Yogyakarta: UNY Press.
Mustikasari, A. (2008). Mengenal media pembelajaran. Diambil pada tanggal 26 Oktober 2013, dari http://eduarticles.com/mengenal-mediapembelajaran/.

Purnama, S.K. (2010). Kepelatihan bulutangkis modern. Surakarta: Yuma Pustaka.

Smaldino, S.E., Lowther, D.L., \& Russell, J.D. (2008). Instructional technology and media for learning (9th ed). Pearson: Merrill Prentice Hall.

Slavin, R.E. (1991). Educaional psychology: theory into practice. $\left(3^{\text {rd }} e d\right.$.). New Jersey: Prantice Hall.

Sofyan, A.F., \& Purwanto, A. (2008). Digital multimedia: animasi, sound editing, \& video editing $\left(l^{\text {st }}\right.$ ed $)$. Yogyakarta: $\mathrm{CV}$ Andi Offset.

Sudarmawan \& Ariyus, D. (2007). Interaksi manusia \& komputer $\left(\begin{array}{ll}l^{\text {st }} & e d .\end{array}\right)$. Yogyakarta: CV Andi Offset.

Sugiyono. (2011). Metode penelitian pendidikan: pendekatan kuantitatif, kualitatif, dan $R$ \& $D$. Bandung: Alfabeta.

Suyanto, M. (2004). Analisis \& desain aplikasi multimedia untuk pemasaran. $\left(l^{\text {st }}\right.$ ed). Yogyakarta: CV Andi Offset.

Suyanto, M. (2005). Multimedia alat untuk meningkatkan keunggulan bersaing $\left(2^{\text {nd }}\right.$ ed.). Yogyakarta: CV Andi Offset.

Winarno, et al. (2009). Teknik evaluasi multimedia pembelajaran. Yogyakarta: Genius Prima Media.

Woolfolk, A.E. (2004). Educational psychology $\left(6^{\text {th }} e d.\right)$. Boston: Pearson Allyn and Bacon.

Yousif, B.F., \& Yeh, K.S. (2011). Badminton training machine with impact mechanism. Journal of Engineering Science and Technology, 6, 61-68.

Zandem, J.W., \& Pace, A.J. (1984). Educational psychology in theory and practice (2nd ed). New York: Random House, Inc. 